\title{
Exploring Definitions and Practices of Responsible Tourism in Kinabalu National Park, Sabah, Malaysia*
}

\author{
Jennifer Kim Lian Chan, Tay Kai Xin \\ Universiti Malaysia Sabah, Sabah, Malaysia
}

\begin{abstract}
Responsible tourism is part of alternative tourism that is able to replace mass tourism. Kinabalu National Park is a nature-based tourism destination that has been declared by the United Nations Educational, Scientific, and Cultural Organization World Heritage Committee (UNESCO WHC) as a World Natural Heritage Site. This paper presents an exploratory research work in exploring and identifying the definition and practices of responsible tourism by the tour operators and park management on Kinabalu National Park, Sabah. Qualitative method is used to collect data through 21 in-depth interviews with tour operators in Sabah who operate tours at the Kinabalu National Park and two interviews with park management. This paper defines responsible tourism from the perspective of tour operators, as a form of tourism that creates a better destination for tourists and local communities, minimizes negative impacts, and is related to sustainability, ecotourism, green tourism, and environmental friendliness; it also relates to responsible tourism practices as implemented by the tour operators and park management of Kinabalu Park. The findings of this paper showed that the practice of responsible tourism is limited when implemented by tour operators in Kinabalu National Park due to the fact that the Kinabalu Park is under the management of Sabah Parks.
\end{abstract}

Keywords: practices of responsible tourism, tour operators’ perspective, park management, Kinabalu National Park

\section{Introduction}

Tourism is seen as a high environment impact industry by its operations and is regarded as the largest industry worldwide (World Travel and Tourism Council [WTTC], International Federation of Tour Operators [IFTO], International Hotel and Restaurant Association [IH\&RA], International Council for Cruise Lines [ICCL], United Nations Environment Programme [UNEP], 2002). The Earth Summit in Rio de Janeiro in 1992 highlighted the importance of responsible tourism through the Rio Declaration, which articulated the main principles of sustainable development in the 21st century (WTTC et al., 2002; Merwe \& Wocke, 2007). "Responsible tourism" is a term first used by South Africa through a White Paper on "Development and Promotion of Tourism in South Africa" in 1996. The first Responsible Tourism Conference led to the "Cape Town Declaration” in 2002 where responsible tourism was defined as a three-tiered approach: to

\footnotetext{
* Acknowledgement: The funding for this project was made possible through a research grant obtained from the Ministry of Higher Education, Malaysia under the Long Term Research Grant Scheme 2011 [LRGS Grant No.: JPT.S (BPKI)2000/09/01/015Jld.4(67)].

Jennifer Kim Lian Chan, professor in Tourism and Hospitality Management, Faculty of Business, Economics, and Accountancy, Universiti Malaysia Sabah.

Tay Kai Xin, master's scholar, Faculty of Business, Economics, and Accountancy, Universiti Malaysia Sabah.

Correspondence concerning this article should be addressed to Jennifer Kim Lian Chan, Faculty of Business, Economics, and Accountancy, Universiti Malaysia Sabah, Kota Kinabalu, Sabah, Malaysia. Email: jkimchan@yahoo.co.uk. Tel.: +6-088-320-000.
} 
increase the quality of local community life, create better business opportunities, and improve experiences for tourists. Likewise, the key to success of this approach is cooperation among the public and private sectors, tourists, and communities.

Tourism stakeholders unanimously agree that the practice of responsible tourism is needed in the tourism industry to continually maintain or even improve the quality of tourism services (Budeanu, 2005). The tourism industry helps in creating awareness of nature, heritage sites, and cultural conservation and also contributes to economic development through creating employment and business opportunities, infrastructure improvement, and increase in foreign exchange and tax revenue (Siti-Nabiha, Abdul Wahid, Amran, Che Haat, \& Abustan, 2008). However, the main drawback of the tourist sector is that its operations are often not very sustainable (Wijk \& Persoon, 2006). Tourism development contributes to the depletion of natural resources, results in multiple forms of pollution, and may have a deep physical impact (Wijk \& Persoon, 2006). Therefore, responsible tourism needs to take into consideration tourism destination planning to ensure that the undesired impacts of tourism are kept to the minimum.

There are four main stakeholders in the tourism industry, which are the government, businesses, tourists, and communities. The main roles of government are making policies, implementing and enforcing rules and regulations, as well as marketing the industry (Gough, 2008). The communities who are involved in the tourism industry are also considered as tourism stakeholders. Tourists are main stakeholders, too, because they are the reason for the existence of the industry and play a significant role in influencing how other stakeholders run their tourism businesses, especially tour operators. Tour operators are the intermediaries between tourism suppliers and tourists (UNEP, 2005). Previously, tour companies considered environmentalists and environmental regulations as enemies but then obeyed them reluctantly (Cairncross, 1995). However, corporate attitudes to environmental issues have changed significantly when the green concept started to be embedded into the tour operator business (Cairncross, 1995); these were fuelled by the advocacy of three professional bodies, which were pressure groups such as tourism concern, green flag and the campaign for environmentally responsible tourism, and the media (Swarbrooke, 1999).

The study site of this paper is Kinabalu National Park, an icon of Sabah and also one of the oldest world heritage sites in Malaysia; it is well-known domestically as well as internationally due to its flora diversity and suitability for climbing. Kinabalu National Park is a protected area under category II identified by the International Union for Conservation of Nature (2000); it has also been declared by the United Nations Educational, Scientific, and Cultural Organization World Heritage Committee (UNESCO WHC, 2013) as a World Natural Heritage Site. Privatization has been implemented in Kinabalu Park since 1998, but it is still managed by a local authority, namely, Sabah Parks (Goh \& Yusoff, 2010). However, the role of a tour operator cannot be neglected, because Kinabalu Park is one of the main destinations packaged by tour operators and sold to tourists. The duty of the tour operator is to practise responsible tourism in designing and planning Kinabalu National Park tour packages; in other words, they need to ensure the sustainability of Kinabalu Park resources when designing the said packages.

Therefore, this paper presents empirical evidence on the practices of responsible tourism as implemented by Sabah Parks and tour operators at Kinabalu National Park, Sabah. The purposes of this paper are: to define responsible tourism from the perspective of tour operators and to examine the responsible tourism practices of tour operators and park management (Sabah Parks). 


\section{Literature Review}

\section{Responsible Tourism}

The literature records a variety of definitions for responsible tourism. According to the Government of South Africa Department of Environmental Affairs and Tourism (1996, p. 11), responsible tourism is defined as "tourism that promotes responsibility to the environment through its sustainable use; responsibility to involve local communities in the tourism industry; responsibility for the safety and security of visitors and responsible government, employees, employers, unions, and local communities”. Moreover, responsible tourism is also simply defined by the Tourism Department of the City of Cape Town (2009, p. 4) as "tourism that creates better places for people to live in, and better places to visit”. Spenceley, Relly, Keyser, Warmeant, McKenzie, Mataboge, ..., and Seif (2002, p. 8) defined that responsible tourism "is about providing better holiday experiences for guests and good business opportunities for tourism enterprises while enabling local communities to enjoy a better quality of life through increased socio-economic benefits and improved natural resource management". The Centre of Responsible Travel (2009, p. 17) defined responsible tourism as "tourism that maximises the benefits to the local communities, minimises negative social or environmental impacts, and helps local people conserve fragile cultures and habitats or species”, whereas Chan (2010) viewed it as being grounded in environmental and social principles and good practices consisting of strong ethical values.

From the definition of responsible tourism given by the scholars above, three main elements were found to be important, which include: building a better place for local community; enhancing the tourists' experiences in destinations; and creating better business opportunities for tourism enterprises. Goodwin (2012) defined responsible tourism as a form of tourism that takes responsibility, while responding and taking action to address the social, economic, and environmental issues of sustainability that arise in a destination (Goodwin, Font, \& Aldrigui, 2012). Responsible tourism emerged from a question frequently asked by researchers, which is, "who should be responsible for mitigating impact?” (Miller, 2001; Sin, 2010; Budeanu, 2005; Frey \& George, 2010).

A declaration on responsible tourism in destination was agreed by 280 delegates including inbound and outbound tour operators, national park management, provincial conservation authorities, tourism professionals, tourism authorities, non-governmental organizations (NGOs), and other tourism stakeholders, from 20 countries at the Cape Town Conference in 2002. The Cape Town Declaration called upon tourism enterprises and trade associations in the tourism sector to adopt a responsible approach, to commit special responsible practices, and to report progress in a transparent and auditable way; the declaration also made the commitment to “... work with others to take responsibility for achieving the economic, social, and environmental components of responsible and sustainable tourism” (Tourism Department of the City of Cape Town, 2002, p. 5).

\section{The Practices of Responsible Tourism by Government and Tour Companies}

Azam and Sarker (2011) suggested two governance mechanisms of responsible tourism through institutional governance and private initiative. Institutional governance refers to the utilisation of state action and certification or eco-label. The proactive involvement of both the public and private sectors is needed to step towards sustainability regardless of whether the country is developed or developing (Azam \& Sarker, 2011). Impartial policies are needed to take place in order to minimise the negative impacts. Institutional strategies may include the specifics of the tourism facilitation, investment initiatives, development research, marketing research, priority tourism development areas, marketing and promotional strategies in various niche markets, air transport, cruise strategies, tourism education, and training strategy to achieve the policy's goals (Telfer \& Richard, 2008; Azam \& Sarker, 2011). 
However, awards and eco-labels can help consumers to differentiate between homogeneous tourism products and environmentally benign tourism products and also encourage more attention to the environment by producers (Font \& Tribe, 2001). Numerous studies have been conducted to verify the certification and product eco-label scheme as useful tools to motivate tourism suppliers to play a proactive role in the tourism industry (Font \& Tribe, 2001; Font \& Buckley, 2001; Font, 2002; Furqan, Som, \& Hussin, 2010; Ayuso, 2006; Mihalic, 2000; Gulbrandsen, 2005; Lee, 2001). Green tourism certification can be defined as a voluntary procedure that assesses, audits, and gives written assurance that a facility, product, or service meets specific standards and can be awarded a marketable logo to those that meet or exceed baseline standards (Furqan et al., 2010). The eco-label enables tourism enterprises to develop high-quality and environmentally-friendly tourism products and services; and tourists are made able to make informed choices while selecting a holiday package (Sasidharana, Sirakayab, \& Kerstetter, 2002). In addition, the aim of certification is to foster responsible environmental, social, and cultural behaviour to produce and consume a environmentally-friendly product (Furqan et al., 2010). The process of green tourism certification has been suggested by Sasidharana et al. (2002) to be broadly classified into six central steps: (1) tourism sector selection; (2) environmental impact evaluation; (3) criteria development; (4) final criteria selection; (5) green tourism certification; and (6) periodic recertification.

Moreover, the government has potentially a wide range of powers to control the scale and type of tourism development and to pursue policies for the wider care of the environment. A mix of policy and planning measures can be used by the government to safeguard environmental resources, which include having protected landscapes, resource reserves, naturally biotic areas, or anthropological reserves and multiple-use management or managed resources (Holden, 2000). Destination areas are generally preoccupied with trying to quantitatively determine the number of tourists that could be accommodated in an area without damaging environmental resources and social changes (Holden, 2000). Vlaicu (2010) also agreed that the carrying capacity of the tourist area needs to be considered to limit the environmental impact. The technique of carrying capacity is to limit the acceptable change or to the acceptable use instead of quantifying the number of tourists, as it can involve a variety of interested stakeholders (Holden, 2000) such as tour operator businesses and small and medium enterprises.

Local Agenda 21 (LA21) is a sustainable development strategy and an action programme to be implemented which is usually initiated by the local authority. Its success hinges on the close cooperation among the local community, NGOs, private entreprises, and others (UNEP, 2003). The whole process of LA21 implementation can be broken down into three components, which are: establishing effective structures for multi-stakeholder participation, both in setting the direction for tourism for the community and in working together to develop and manage it; identifying a strategy for sustainable tourism within the context of a wider sustainable development strategy that reflects stakeholder views and which allows tourism management to be integrated with other management functions in the destination; and identifying and implementing a set of actions, in line with the strategy, which address the economic, social, and environmental sustainability of tourism in the area (UNEP, 2003). Siti-Nabiha, George, Abdul Wahid, Amran, Abustan, and Mahadi (2011) noted that Malaysia is in dire need to introduce and effectively implement LA21 for sustainable tourism, because political commitment to implement the strategies and enforce policies and regulations is needed to ensure that responsible tourism practices take place in Malaysia. 
Even though the government has authority and a range of powers at its disposal to protect the destination, the commitment of the private sector is also needed to enhance the chances of success (Azam \& Sarker, 2011). Tourism involves a wide range of related parties or stakeholders from almost every domain, who have different interests. Thus, participation of all stakeholders is very important, especially because tour operators play an intermediary role between supply and demand (Risteskia, Kocevskia, \& Arnaudov, 2012). The government should ratify private business enterprises or tour operators' investment on a competitive basis, but respective tourism institutions can regulate and monitor the management of tour operators in a destination (Azam \& Sarker, 2011). Based on prior studies, the responsible tourism practices which can be applied by tour operators are cleaner production (CP), green supply chain management (GSCM), local capacity development (LCD), and awareness-raising.

CP can be a tool to practise responsible tourism (Lee, 2001). It can be defined as "the continuous application of an integrated preventive environmental strategy applied to processes, products, and services to increase eco-efficiency and reduce risks to humans and the environment” (UNEP, 2001, p. 29). CP brings several benefits to private enterprises like minimisation of resources used and increase in productivity, decrease in contamination and human health risks, better environmental compliance, better public relations with other stakeholders, increase in competitiveness, and improved public image (Ashton, Luque, \& Ehrenfeld, 2002). Lee (2001) stated that local community and companies at the destination could adopt CP as a strategy in addressing areas such as waste and resource use in the production process as well as procuring public services.

GSCM is also one of the methods to practise responsible tourism. GSCM can be defined as the way in which innovation in supply chain management and industrial purchasing may be considered in the context of the environment (Green, Morton, \& New, 1996); it also includes integrating environmental thinking into supply chain management, including product design, material sourcing and selection, manufacturing processes, delivery of the final product to the customers, as well as end-of-life management of the product after its useful life (Srivastava, 2007). GSCM is not just about considering environment in supply chain decision-making processes but also about productivity and making profit (Nikbakhsh, 2009).

Four GSCM practices were suggested by Zhu, Sarkis, and Lai (2008) which included internal environmental management, external GSCM or supplier and customer relationship, investment recovery, and eco-design. UNEP (2005) listed a few ways to practise GSCM, such as to develop a sustainable supply chain management policy and action plans; support suppliers in reaching the sustainability standards set by the company; and promote compliance with sustainability standards, for instance, offering incentives to encourage suppliers to meet the minimum standards of GSCM. Budeanu (2009) argued that environmental supply chain management can be applied by tour operators to practise responsible tourism. The author noted that undeveloped drivers for improved environmental performances, missing regulatory frameworks, and lack of cost incentives result in tour operators to have a relaxed attitude with respect to GSCM adoption.

LCD through self-empowerment was promoted by Biswas, Bryce, and Diesendorf (2001) but redesigned and applied by Azam and Sarker (2011) as an LCD model of responsible tourism (see Figure 1). An LCD model of community-based enterprise comprises two sections on tourism management, which are accommodation service management and traditional product preparation and marketing, to support local empowerment and environmental development (Azam \& Sarker, 2011). Participation of local communities in the decision-making process is highly required to ensure the acceptability of tourism (Wahab, 1997). Responsible tourism or ecotourism is emphasised to help local communities in terms of income and knowledge 
and to improve the living standards in the tourist destination, and therefore, commitment and participation are indispensable (Chikumbi, 2006; Pratt, Rivera, \& Bien, 2011; Risteskia et al., 2012). The practice of LCD by external agencies such as tour operators, local authority, NGOs, and banks, in cooperation with the local community, contributes to the practice of responsible tourism via local job creation, improved local facilities, and environment via service management, economic gain from the sale of traditional products, and improved social equity.

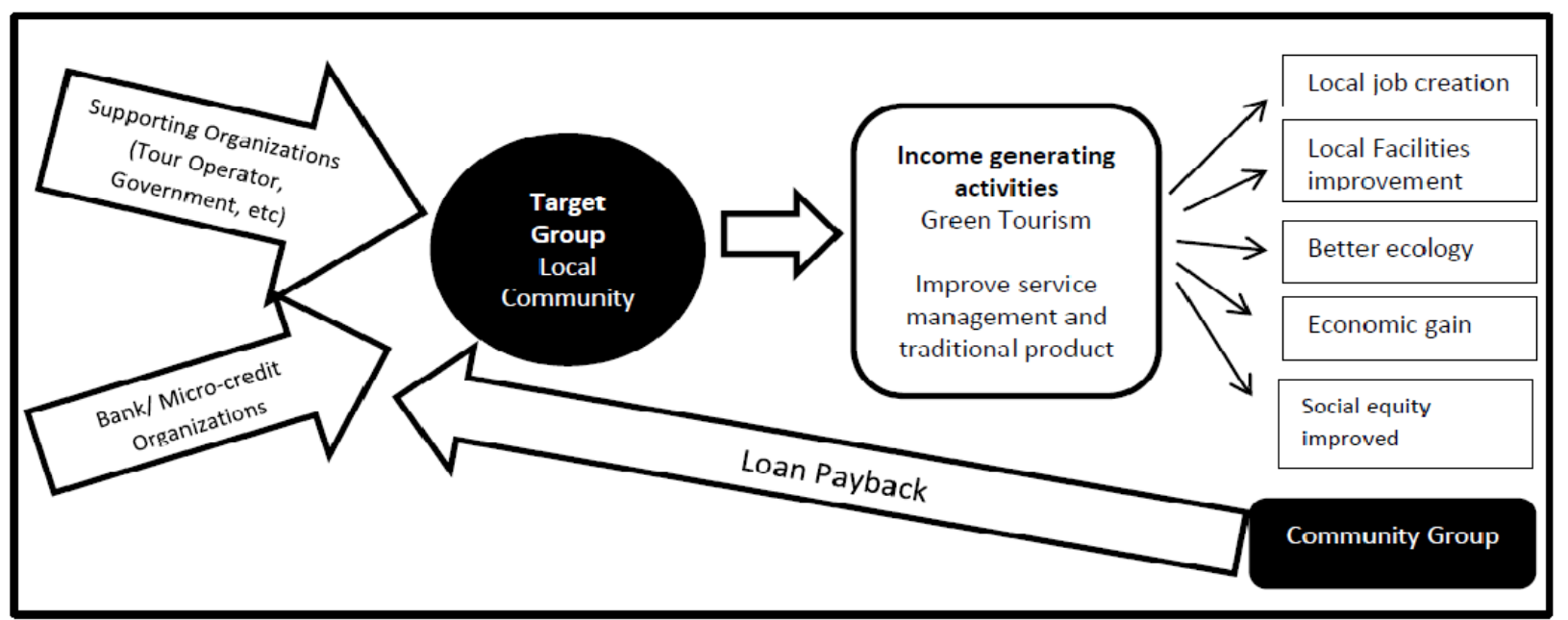

Figure 1. LCD model of responsible tourism. Source: Biswas et al. (2001); redesigned and applied by Azam and Sarker (2011).

The practice of LCD can be implemented by the tour operators through the building of partnerships with local stakeholders to influence the decisions of national and local authorities on environmental planning and management. Tour operators can help in conserving the natural and cultural heritage and promoting local products to tourists; they also play an informative role in spreading the message of sustainability more widely to local stakeholders through GSCM and engaging in philanthropy and charitable donations to support certain projects, such as tree planting.

Awareness-raising tools can be used by tour operators to influence tourist behaviour towards responsible tourism (Budeanu, 2007). Tour operators are ideally positioned to support and influence responsible actions by tourists by way of promoting appropriate behaviour in pre-departure information, through a fair portrayal of the destination and the local cultures, and to continue raising the awareness of sustainability issues throughout the tour and excursions and in any post-holiday information (UNEP, 2005; Khairat \& Maher, 2012). However, it is also the responsibility of the government to promote the responsible tourism concept through educational programs and awareness campaigns (Budeanu, 2007).

This tool is also very important to citizen-consumers in fostering more sustainable consumption to support responsible tourism (Martens \& Spaargaren, 2005). Budeanu (2007) noted that compared to corporate and governmental efforts, tourists must be less interested in adopting sustainable lifestyles or supporting responsible tourism products. Therefore, strategies are orchestrated to influence tourists to become more proactive in responsible tourism practices. The strategies which can be implemented by tour operators include: the education and communication of the sustainability message to tourists to raise the awareness of responsible tourism, through media and publishing; private enterprises may develop or adopt a responsible tourism code of conduct; and training can be given to the sales staff at the travel agents and tour operators (UNEP, 2005). 
Risteskia et al. (2012) openly and unequivocally concluded that if no detailed or thorough analysis and adequate research were conducted, spatial planning and development in general can become unsustainable. The author suggested that spatial planning can be used as an instrument for coordinating the socio-economic development through preventing environmental problems and simultaneously protecting the natural and cultural environment. According to Beedasy and Whyatt (1999), spatial planning is essentially a decision-making process which requires the identification, analysis, combination, and evaluation of relevant criteria to meet specific objectives. Spatial solutions can be defined as a pattern of ecosystems or land use that will conserve the bulk of, and the most important attributes of, biodiversity and natural processes in any region, landscape, or major portion thereof (Forman \& Collinge, 1997). However, the challenges of planning are to ensure efficient use of limited land resources and ensure balanced regional business development and use of resources (Risteskia et al., 2012). Spatial planning can also involve important principles of sustainability.

\section{Research Approach}

This is an exploratory research on understanding tour operators' perspectives. The study envisages the understanding of the governing pattern of tour operators, to probe into the depth of respondents' thoughts and to extract the data that are grounded in the field. Social constructivism-interpretivism is used as an interpretive framework for this research due to its objectives in exploring human behaviour in relation to their understanding and practices of responsible tourism in Kinabalu National Park. An inductive approach is adopted, because the objectives of this study are to gain an understanding of responsible tourism from the tour operator's perspective, as opposed to the deductive approach which focuses on the breadth of knowledge.

The qualitative method is used to collect data through 21 in-depth interviews with tour operators in Sabah and two interviews with managerial staff from Sabah Parks. The respondents are tour operators licensed in Kota Kinabalu, Sabah, Malaysia and who currently operate tours to Kinabalu National Park. According to the statistics provided by Sabah Tourism Board (2013), there are a total of 197 licensed tour operators in Sabah, of which Kota Kinabalu has 169. Eligible respondents were selected and shortlisted after a screening stage, carried out via email and telephone call. Only tour operators selling Kinabalu Park tour packages were selected, and their consent to be involved in an in-depth interview was obtained.

The purposeful sampling strategy is used in this paper to describe a sub-group in an in-depth manner. Open-ended questions are used during interviews due to the fact that the responses permit one to understand the world as seen by the respondents. Interview protocol is used during the interviews in order to achieve the aims of this research. The interviewer does not follow a structured questionnaire but rather use it to facilitate the direction of the interview, especially when the interviewer is at a loss for words. Likewise, the questionnaire is also used in a flexible way to accommodate the nature of the interviewee as well as the environment where the interview was carried out. The questions asked during the interview were: (1) How do you define "responsible tourism"? and (2) How is responsible tourism practised by your company at Kinabalu Park?

Interpretative phenomenological analysis (IPA) with CREATIVE steps is used for data analysis. The data were analysed by transcribing the audio-recorded interviews verbatim into typed text. The eight CREATIVE steps consisted of: (1) consider the study's research questions and purpose statement; (2) read through the transcripts to gain a holistic sense of the data; (3) examine the data for information related to the research 
questions; (4) assign labels to those units of information that capture the motivation and challenges faced by tour operators; (5) thematise the data; (6) interpret the emergent themes as respondents relate to the study's research questions and purpose statement; (7) verify the trustworthiness of the findings by examination of previous research to frame findings (Shenton, 2004); and (8) engage in the writing process to describe the findings (Pitney \& Parker, 2009).

\section{Findings}

\section{The Definition of Responsible Tourism From Tour Operators' Understanding}

The findings showed that the definitions of responsible tourism are related to creating a better destination, minimisation of negative impacts, ecotourism, sustainability, benefit to local community, green tourism, environmental-friendliness, improvement of tourists' experiences, and the encouragement of the "reuse, recycle, and reduce” practice.

Table 1

The Definition of Responsible Tourism

\begin{tabular}{|c|c|}
\hline Themes & Informant responses \\
\hline $\begin{array}{l}\text { Creating a better destination through conservation and } \\
\text { protection (Tourism Department of the City of Cape Town, } \\
\text { 2009; Goodwin, 2012; Centre of Responsible Travel, 2009) }\end{array}$ & $\begin{array}{l}\text { Conservation to preserve nature for the next generation } \\
\text { (Interview informants } 1,6,11,15,16,18,19 \text {, and } 20 \text { ) } \\
\text { Preserve the destination for business sustainability } \\
\text { (Interview informants } 9 \text { and } 10 \text { ) }\end{array}$ \\
\hline Reducing impacts (Centre of Responsible Travel, 2009) & $\begin{array}{l}\text { Reduce the negative impact on nature through the packaging } \\
\text { (Interview informant 7) } \\
\text { Reduce the impact to destination } \\
\text { (Interview informants } 11,14,17 \text {, and 21) } \\
\text { Low impact on forest and natural resources } \\
\text { (Interview informant 20) }\end{array}$ \\
\hline $\begin{array}{l}\text { Sustainability of the destination (Government of South Africa } \\
\text { Department of Environmental Affairs and Tourism, 1996; } \\
\text { Tourism Department of the City of Cape Town, 2009; UNEP, } \\
\text { 2005) }\end{array}$ & $\begin{array}{l}\text { Sustainability of destination } \\
\text { (Interview informants } 1 \text { and 3) } \\
\text { Alternative tourism, sustainable tourism } \\
\text { (Interview informant 19) }\end{array}$ \\
\hline $\begin{array}{l}\text { Benefiting local community (Government of South Africa } \\
\text { Department of Environmental Affairs and Tourism, 1996; } \\
\text { Tourism Department of the City of Cape Town, 2009; } \\
\text { Goodwin, 2012; Centre of Responsible Travel, 2009; Spenceley } \\
\text { et al., 2002) }\end{array}$ & $\begin{array}{l}\text { Involved with the local community in tourism develo } \\
\text { (Interview informants } 8 \text { and 11) } \\
\text { Improve the well-being of local people } \\
\text { (Interview informant 9) }\end{array}$ \\
\hline $\begin{array}{l}\text { Improvement of tourists' experiences by enhancing tourists' } \\
\text { satisfaction and improving safety (Government of South Africa } \\
\text { Department of Environmental Affairs and Tourism, 1996; } \\
\text { Tourism Department of the City of Cape Town, 2009; } \\
\text { Spenceley et al., 2002) }\end{array}$ & $\begin{array}{l}\text { Tourists' satisfaction } \\
\text { (Interview informant 8) }\end{array}$ \\
\hline Ecotourism (New discovery emerged from the data) & $\begin{array}{l}\text { Similar with the definition of ecotourism } \\
\text { (Interview informants 8, 10, and 20) }\end{array}$ \\
\hline The practices of 3R's (New discovery emerged from the data) & $\begin{array}{l}\text { Encourage the use of the "recycle, reduce, and reuse" concept } \\
\text { (Interview informant 21) }\end{array}$ \\
\hline
\end{tabular}

Table 1 shows the key findings of the responsible tourism definition from tour operators' perspectives. There are seven definitions of responsible tourism based on interview responses. Firstly, the majority of tour operators interpreted the meaning of responsible tourism as conservation and protection of the destination. This will create a better destination for local residents and also for tourists to visit. This interpretation is similar to the definition given by the Tourism Department of the City of Cape Town (2009) as tourism is to create a better place for local residents and also for visitors. 
According to interview informants 1 and 6, "Responsible tourism is to reduce the stress on the environment in order to conserve it for our next generation". Another interview informant 9 expressed, "We make money from nature; of course we are the ones responsible to conserve the place". This implies that the concept and practice of responsible tourism relate to business sustainability, preservation of nature, and responsibility for the next generation.

Responsible tourism refers to minimise the negative social and environmental impacts (Centre of Responsible Travel, 2009). Based on the findings, a number of informants interpreted that responsible tourism is to minimise the negative impact on nature. This can be evidenced in the following quotes:

“... We can package the product that has less negative impact on the environment, such as using green engine cars to reduce carbon dioxide emissions... to avoid air pollution” (Interview informant 7).

"At KNP (Kinabalu National Park), there is an abundance of flora; too much CO2 will kill it” (Interview informant 20).

Some informants indicated that responsible tourism implied sustainability or alternative tourism and the two definitions are difficult to differentiate, which were also mentioned by Mitani (1993). This definition is reflected in the quotes as follows: "It refers to the sustainability of the destination..." (Interview informant 1); “... to sustain the nature and environment...” (Interview informant 3); "Responsible tourism, green tourism, and sustainable tourism are in the category of alternative tourism, so the principles are almost the same as that of conservation, bringing tourists to unexplored areas, nature, and adventure places” (Interview informant 19).

There were many prior studies showing that responsible tourism is the responsibility of involving the local residents into tourism industry and bringing advantages for them through tourism destination (Government of South Africa Department of Environmental Affairs and Tourism, 1996; Tourism Department of the City of Cape Town, 2009; Goodwin, 2012; Centre of Responsible Travel, 2009; Spenceley et al., 2002). Responsible tourism is also defined as a means of benefiting local communities from the result of the data. This can be referred from the following quotes:

“... Involve the local community to bring awareness and (help) to educate the tourists..." (Interview informant 8).

“... Bring benefits to the local people in the destination” (Interview informant 9).

“... Help local communities in the area...” (Interview informant 11).

There is only one respondent who defines responsible tourism as to improve the tourists' experience. The quotes from the respondents show as: “... our objective is to bring tourists to enjoy their holiday, so we are responsible to provide the thing (package) for them to enjoy in the destination” (Interview informant 8). This is in line with Spenceley et al. (2002) who defined responsible tourism as about providing better holiday experiences for guests.

The findings from tour operators show that the definition of responsible tourism is similar with that of ecotourism. Two informants responded that, “... ecotourism is, so we are more familiar with ecotourism rather than responsible tourism...” (Interview informant 8)/“... this is my first time to hear about responsible tourism, but I think it is the same with ecotourism and ecotourism is promoted by Sabah Parks” (Interview informant 10).

Interestingly, we discover a new definition of responsible tourism from data analysis, which is 3R's practice including reduce, reuse, and recycle of the waste (e.g., paper, energy, water). There is only one interview informant (21) who defined responsible tourism as the following quote: 
"It is similar to reuse, recycle, and reduce concept... to use environmental friendly products... to be responsible (to) avoid pollution in destination”.

The findings of responsible tourism can be categorized as: (1) creating a better destination through conservation and protection; (2) reducing negative impacts; (3) sustainability of the destination; (4) benefiting the local community; (5) improvement of tourists' experiences by enhancing tourists' satisfaction and improving safety; (6) ecotourism; and (7) the practice of 3R's (reduce, reuse, and recycle).

\section{The Practices of Responsible Tourism by Tour Operators and Sabah Parks}

The findings of the practices by tour operators and Sabah Parks are shown in Table 2 below. The practices of responsible tourism by tour operators include creating awareness to visitors, supporting the local community, obedience to the rules and regulations set by Sabah Parks, supply chain management, and reuse of materials. The practices of responsible tourism by Sabah Parks in the Kinabalu Park include local community involvement, zone division, and the issuance of licenses to qualified mountain guides, cooperation among associations and NGOs, and conservation.

Table 2

The Practices of Responsible Tourism by Tour Operators and Sabah Parks

\begin{tabular}{|c|c|}
\hline Themes which emerged from tour operators & Informant responses \\
\hline Awareness-raising & $\begin{array}{l}\text { Train the staff, especially tour guides and front line staff } \\
\text { (Interview informants } 18 \text { and 19) } \\
\text { To raise the awareness of tourists } \\
\text { (Interview informants 2, 6, 7, 8, 10,13,14,16, 19, and 20) } \\
\text { Creating awareness through website } \\
\text { (Interview informants } 12 \text { and 18) }\end{array}$ \\
\hline Rules and regulation compliance & $\begin{array}{l}\text { Obey the rules and regulations set by Sabah Parks } \\
\text { (Interview informants 2, 4, 6, 10, and 13) }\end{array}$ \\
\hline LCD & $\begin{array}{l}\text { Promote homestay to tourists } \\
\text { (Interview informant 9) } \\
\text { Community service } \\
\text { (Interview informant 2) }\end{array}$ \\
\hline $\mathrm{CP}$ & $\begin{array}{l}\text { Reuse used materials } \\
\text { (Interview informant 11) }\end{array}$ \\
\hline Supply chain management & $\begin{array}{l}\text { Choose environmentally-friendly suppliers for tour package } \\
\text { (Interview informant 11) }\end{array}$ \\
\hline Themes which emerged from Sabah Parks officers & Informant responses \\
\hline Local community involvement & \begin{tabular}{|l|} 
Bring benefits to local community \\
Local communities can help to protect the area
\end{tabular} \\
\hline Zone division & Protect the sensitive zone \\
\hline Licenses issued to qualified mountain guides & $\begin{array}{l}\text { Issued the licence to qualified guides } \\
\text { Only licensed guides can lead visitors to climb the mountain } \\
\text { Annual training to mountain guides }\end{array}$ \\
\hline Cooperation among associations and NGOs & $\begin{array}{l}\text { Organising events with NGOs } \\
\text { Meeting and opening discussion with NGOs such as World } \\
\text { Wide Fund for conservation purposes }\end{array}$ \\
\hline Conservation strategies & $\begin{array}{l}\text { Scientific understanding of plants and animal species } \\
\text { Identify the factors threatening the continued survival of the } \\
\text { species in their natural habitats } \\
\text { Organisation of resources to protect rare and endangered species } \\
\text { from further disturbances }\end{array}$ \\
\hline Carrying capacity & $\begin{array}{l}\text { Only } 10 \% \text { of the area is allowed for use } \\
\text { Limited number of climbers }\end{array}$ \\
\hline
\end{tabular}


Five practices of responsible tourism have been implemented by the tour operators, which are: awareness-raising; LCD; CP; supply chain management; and compliance with rules and regulations. According to the responses from park management, six themes have emerged, which are: local community involvement; zone division; licences issued to qualified mountain guides; cooperation among associations and NGOs; conservation strategies; and carrying capacity.

According to the interview responses, it is recognised that awareness-raising is the main responsible tourism practice in Kinabalu National Park. This can be evidenced in the following responses:

“... What we can do is only give training to the tour guide and driver because they are the ones who deal with the guests along the trip. Our website also promotes the Kinabalu Park and creates awareness on the need to protect the place" (Interview informant 18).

"We will make our front line staff know about responsible tourism and we have a coordinator at Kinabalu Park who will brief the climber before he/she climbs the Mount Kinabalu” (Interview informant 19).

Awareness-raising is also suggested by Budeanu (2007) and UNEP (2005) to be used in influencing tourists' attitudes toward responsible tourism packages. Awareness-raising enables tour operators to change tourists' attitudes from reactive to proactive in responsible tourism practices. However, the role of government is also played significantly in awareness-raising through various educational programmes and awareness campaigns (Budeanu, 2007).

Most of the respondents pointed out that Kinabalu Park is under the management of Sabah Parks. Thus, tour operators cannot perform many responsible tourism practices on site. If they want to organise activities, they need to get an approval from Sabah Parks. What tour operators can do is to create awareness and obey the rules and regulations set by Sabah Parks. These themes can be supported by the following responses:

"We only can educate the tourists, because the other things like programmes or activities are not up to us, it depends on Sabah Parks” (Interview informant 13).

"Kinabalu Park is fully managed by Sabah Parks; we only can share the information with tourists through the internet" (Interview informant 12).

“... Can’t do much in Kinabalu Park because it is managed by SP (Sabah Parks). If we want to organise an activity, we need to apply through Sabah Parks and the process is complicated and not that easily get approved” (Interview informant 1).

“We didn’t do much for responsible practices in KNP because KNP is managed by Sabah Parks; if we want to do anything in KNP, we need to apply for approval from Sabah Parks, it involves many procedures" (Interview informant 8).

“... Obeying the rules and regulations set by Sabah Parks, like the government does have some of the implementation which is certain trail only allow going in because of safety issue and protecting the environment. Another implementation is all of buses and vans are no allowed to park inside of KNP in order to avoid air and noise pollution and also traffic jam” (Interview informant 2).

Interestingly, informants revealed that their concern is more on business compared to responsible tourism practice. This can be proven in the following quote:

"Our company has arranged at least one tour guide for a trip even though only two tourists. Because the tour guide can educate them during the tour to make sure they don't damage the destination... We are doing business but we are not like the NGOs so we don't practise much responsible tourism” (Interview informant 20). 
Another responsible tourism practice is LCD; it is to support local residents around the Kinabalu Park. This can be evidenced as: "Sometimes, people there organise events like "Gotong-royong" around the park, we join them... help them..." (Interview informant 2). "We promote the homestay to guests but normally they don't like to stay there, but Western tourists like it” (Interview informant 9). Responsible tourism is served as an external agency to help local community through cooperation in selling the local products, and also help in terms of service management. Consequently, it brings benefits like job opportunities, local facility improvement, local environmental improvement, economic gain, and improved social equity (Biswas et al., 2001; Azam \& Sarker, 2011).

The concept of "green" can be integrated into supply chain management to design a green tour package, which considers supplier sourcing and selection, package promotion and marketing, and tour operation from pre-departure to post-holiday (Green et al., 1996). The CP is production that integrated preventive environmental strategy (UNEP, 2001).

There is only one respondent who mentioned supply chain management and reuse of used material to build the Mongolia yurt lodge located near the Kinabalu Park. This can be evidenced in the following response:

"I have chosen an environmentally-friendly supplier to offer services to tourists. But it is quite hard in KK (Kota Kinabalu) because they are still not aware about the green issue... Eco... and our company own one Mongolian yurt lodge there which is fully built by reused materials like wood...” (Interview informant 11).

Reuse of used material is categorised into CP; it is because that reuse of used material is to minimise raw resources used, save the cost of building, decrease contamination and human health risks, and promote better environmental compliance. These benefits are also outlined by Ashton et al. (2002). Based on the overall findings, the practice of responsible tourism is limited by tour operators in Kinabalu Park.

Based on respondents from Sabah Parks, Sabah Parks is cooperating with local residents in protecting the park area. Therefore, tourism is a pathway to bring benefits to local communities, in economic and social terms. Other than that, zone division was also set by Sabah Parks to protect the sensitive zone. The respondent explained that, “... Some zones are prohibited from entrance and some zones are only open for researchers and scientists who want to explore new species or do research... but, even so, the place is guarded by park officers, although sometimes the local people still go in without permission". This implies that some local residents are not cooperative with park management.

Licenses are issued to mountain guides who are qualified to lead climbers, and annual training is provided by Sabah Parks to the said guides. Sabah Parks also cooperates with NGOs and associations such as tour operator associations when organising events. Conservation strategies, as responsible tourism practices, are also mentioned by respondents, which include: to understand the plant and animal species of special concern; to know the factors threatening flora and fauna; and to organise resources in order to protect the endangered species, especially the rare orchids. Carrying capacity is also enforced by Sabah Parks in that only $10 \%$ of the landscape is allowed for development and tourism activities, and the number of climbers at any one time is limited.

\section{Conclusion}

In conclusion, this paper has explored the definition of responsible tourism from tour operators' perspectives and also the responsible tourism practices implemented by tour operators and Sabah Parks, with a focus on Kinabalu National Park, Sabah. The definition of responsible tourism refers more to the responsibility 
of tour operators in creating a better destination for local residents, to enhance visitors' experiences, minimise negative impacts, and to help in LCD. The responsible tourism practices included the creation of awareness, support for the local community, compliance with rules and regulations, supply chain management, CP by tour operators, local community involvement, zone division, the licensing of mountain guides, cooperation with NGOs, conservation strategies, and carrying capacity management by park management.

This paper aims to enhance the understanding of responsible tourism and explore the practices of responsible tourism implemented by tour operators and Sabah Parks in Kinabalu National Park. Government authorities can also refer to this research to develop responsible tourism practices by taking tour operators' perspectives into consideration. These findings can be used by tourism practitioners, especially the government (Sabah Parks), as a reference for adopting responsible tourism practices in any destination. This study has explored the practices of responsible tourism in Kinabalu Park from the tour operators' and Sabah Parks' perspectives, but the effectiveness of these practices is unknown. Therefore, future research should focus on examining the effectiveness of the said practices in Kinabalu Park.

\section{References}

Ashton, W., Luque, A., \& Ehrenfeld, J. R. (2002). Best practices in cleaner production promotion and implementation for smaller entreprises. New Haven: IDB Publications, Inter-American Development Bank.

Ayuso, S. (2006). Adoption of voluntary environmental tools for sustainable tourism: Analysing the experience of Spanish hotels. Corporate Social Responsibility and Environmental Management, 13(4), 207-220.

Azam, M., \& Sarker, T. (2011). Green tourism in the context of climate change towards sustainable economic development in the South Asian Region. Journal of Environmental Management and Tourism, 1(3), 6-15.

Beedasy, J., \& Whyatt, D. (1999). Diverting the tourists: A spatial decision-support system for tourism planning on a developing island. International Journal of Applied Earth Observation and Geoinformation, 1(3-4), 163-174.

Biswas, W. K., Bryce, P., \& Diesendorf, M. (2001). Model for empowering rural poor through renewable energy technologies in Bangladesh. Environmental Science and Policy, 4(6), 333-344.

Budeanu, A. (2005). Impacts and responsibilities for sustainable tourism: A tour operator's perspective. Journal of Cleaner Production, 13(2), 89-97.

Budeanu, A. (2007). Sustainable tourist behaviour-A discussion of opportunities for change. International Journal of Consumer Studies, 31(5), 499-508.

Budeanu, A. (2009). Environmental supply chain management in tourism: The case of large tour operators. Journal of Cleaner Production, 17(16), 1385-1392.

Cairncross, F. (1995). Green Inc.: Guide to business and the environment. London: Earthscan Publications, Ltd..

Centre of Responsible Travel. (2009). The market for responsible tourism products: With a special focus on Latin America and Nepal. Hague, the Netherlands: SNV Netherlands Development Organisation.

Chan, J. K. (2010). Building sustainable tourism destination and developing responsible tourism: Conceptual framework, key issues, and challenges. Tourism Development Journal: An International Research Journal, 8(1), 24-32.

Chikumbi, D. C. (2006). Cultural heritage: Celebrating 10 years of institutional cooperation. Lusaka, Zambia: National Heritage Conservation Commission.

Font, X. (2002). Environmental certification in tourism and hospitality: Progress, process, and prospects. Tourism Management, 23(3), 197-205.

Font, X., \& Buckley, R. C. (2001). Tourism ecolabelling: Certification and promotion of sustainable management. Walingford Oxon: CABI Publishing Series.

Font, X., \& Tribe, J. (2001). Promoting green tourism: The future of environmental awards. International Journal of Tourism Research, 3, 9-21.

Forman, R. T., \& Collinge, S. K. (1997). Nature conserved in changing landscapes with and without spatial planning. Landscape and Urban Planning, 37(1-2), 129-135. 
Frey, N., \& George, R. (2010). Responsible tourism management: The missing link between business owners' attitudes and behaviour in the Cape Town tourism industry. Tourism Management, 31(5), 621-628.

Furqan, A., Som, A. P., \& Hussin, R. (2010). Promoting green tourism for future sustainability. Theoretical and Empirical Research in Urban Managment, 8(17), 64-74.

Goh, H. C., \& Yusoff, M. M. (2010). Sustaining tourism development in protected areas. A case of Kinabalu Park. International Journal of Trade, Economics, and Finance, 1(2), 179-183.

Goodwin, H. (2012). There is a difference between sustainable and responsible tourism. World Travel Market. Retrieved from http://www.wtmlondon.com/page.cfm/Action=library/libID=1/libEntryID=86

Goodwin, H., Font, X., \& Aldrigui, M. (2012). Conference report of the 6th International Conference on Responsible Tourism in Destination (pp. 398-402). Sao Paulo, Brazil: University of São Paulo.

Gough, B. (2008). FCS sustainable tourism in SA and regional travel L3. Cape Town: Pearson Education South Africa (Pty), Ltd..

Government of South Africa Department of Environmental Affairs and Tourism. (1996). White paper: The development and promotion of tourism in South Africa. Retrieved from http://scnc.ukzn.ac.za/doc/tourism/White_Paper.htm

Green, K., Morton, B., \& New, S. (1996). Purchasing and environmental management: Interactions, policies, and opportunities. Business Stratem and the Environment, 5(3), 188-197.

Gulbrandsen, L. H. (2005). Mark of sustainability? Challenges for fishery and forestry eco-labeling. Environment, 47(5), 8-23.

Holden, A. (2000). Environment and tourism. New York, NY: Routledge.

International Union for Conservation of Nature. (2000). The World Heritage Convention IUCN technical evaluation reports. Retrieved from http://whc.unesco.org/archive/2000/whc-00-conf202-inf5e.pdf

Khairat, G., \& Maher, A. (2012). Integrating sustainability into tour operator business: An innovative approach in sustainable tourism. Tourismos: An International Multidisciplinary Journal of Tourism, 7(1), 213-233.

Lee, K. F. (2001). Sustainable tourism destinations: The importance of cleaner production. Journal of Cleaner Production, 9(4), 313-323.

Martens, S., \& Spaargaren, G. (2005). The politics of sustainable consumption: The case of the Netherlands. Sustainability: Science, Practice, and Policy, 1(1), 29-42.

Merwe, M. V., \& Wocke, A. (2007). An investigation into responsible tourism practices in the South African hotel industry. South African Journal of Business Management, 38(2), 1-15.

Mihalic, T. (2000). Environmental management of a tourist destination: A factor of tourism competitiveness. Tourism Management, 21(1), 65-78.

Miller, G. (2001). The development of indicators for sustainable tourism: Results of a Delphi survey of tourism researchers. Tourism Management, 22(4), 351-362.

Mitani, S. (1993). Green tourism, environmentally sound rural tourism in Japan: Recommendations for improvement of Japanese green tourism practices. Retrieved from http://pub.maastrichtuniversity.nl/7bfee2a0-2c0b-4939-b6a8-f3a3c5f48bbd

Nikbakhsh, E. (2009). Green supply chain management (Chapter 9). In R. Z. Farahani, N. Asgari, \& H. Davarzani (Eds.), Supply chain and logistics in national, international, and governmental environment (pp. 195-220). Berlin Heidelberg: Springer-Verlag.

Pitney, W. A., \& Parker, J. (2009). Qualitative research in physical activity and the health professions. Champaign, IL: Human Kinetics.

Pratt, L., Rivera, L., \& Bien, A. (2011). Towards a green economy. UNEP. Retrieved from http://www.unep.org/greeneconomy/Portals/88/documents/ger/11.0_Tourism.pdf

Risteskia, M., Kocevskia, J., \& Arnaudov, K. (2012). Spatial planning and sustainable tourism as basis for developing competitive tourist destinations. Procedia-Social and Behavioral Sciences, 44, 375-386.

Sabah Tourism Board. (2013). Kota Kinabalu: Capital city. Sabah Tourism Board. Retrieved from http://www.sabahtourism.com/en/destination/district/1-kota-kinabalu-capital-city/

Sasidharana, V., Sirakayab, E., \& Kerstetter, D. (2002). Developing countries and tourism ecolabels. Tourism Management, 23(2), 161-174.

Shenton, A. K. (2004). Strategies for ensuring trustworthiness in qualitative research projects. Education for Information, 22 , 63-75.

Sin, H. L. (2010). Who are we responsible to? Locals' tales of volunteer tourism. Geoforum, 41(6), 983-992.

Siti-Nabiha, A. K., Abdul Wahid, N., Amran, A., Che Haat, H., \& Abustan, I. (2008). Towards a sustainable tourism management in Malaysia. Lex ET Scientia International Journal, 15(2), 301-312. 
Siti-Nabiha, A. K., George, R. A., Abdul Wahid, N., Amran, A., Abustan, I., \& Mahadi, R. (2011). A field survey of environmental initiatives at selected resorts in Malaysia. World Applied Sciences Journal, 12, 56-63.

Spenceley, A., Relly, P., Keyser, H., Warmeant, P., McKenzie, M., Mataboge, A., ..., \& Seif, J. (2002). Responsible tourism manual for South Africa. South Africa: Department for Environmental Affairs and Tourism.

Srivastava, S. K. (2007). Green supply-chain management: A state-of-the-art literature review. International Journal of Management Reviews, 9(1), 53-80.

Swarbrooke, J. (1999). Sustainable tourism management. New York, NY: CABI Publishing.

Telfer, D. J., \& Richard, S. (2008). Tourism and development in the developing world. Abingdon: Routledge.

Tourism Department of the City of Cape Town. (2002). Cape Town Declaration. Retrieved from http://www.capetown.gov.za/en/tourism/Pages/ResponsibleTourism.aspx

Tourism Department of the City of Cape Town. (2009). Responsible tourism policy for the City of Cape Town. Retrieved from http://www.capetown.gov.za/en/tourism/Pages/ResponsibleTourism.aspx

United Nations Educational, Scientific, and Cultural Organization World Heritage Committee [UNESCO WHC]. (2013). Kinabalu Park. Retrieved from http://whc.unesco.org/en/list/1012

United Nations Environment Programme [UNEP]. (2001). Cleaner production. Montreal: UNEP.

United Nations Environment Programme [UNEP]. (2003). Tourism and local agenda 21: The role of local authorities in sustainable tourism. Paris: United Nations Publication.

United Nations Environment Programme [UNEP]. (2005). Integrating sustainability into business-A management guide for responsible tour operations. Paris, France: UNEP.

Vlaicu, A. (2010). Conventional tourism from sustainable tourism to ecotourism. "Vasile Goldiş" Western University of Arad, 5(1), 43-49.

Wahab, S. E. (1997). Sustainable tourism in developing world. In S. E. Wahab, \& J. J. Pigram (Eds.), Tourism, development, and growth: The challenge of sustainability (pp. 129-146). New York, NY: Routledge.

Wijk, J. V., \& Persoon, W. (2006). A long-haul destination: Sustainability reporting among tour operators. European Managment Journal, 24(6), 381-395.

World Travel and Tourism Council [WTTC], International Federation of Tour Operators [IFTO], International Hotel and Restaurant Association [IH\&RA], International Council for Cruise Lines [ICCL], United Nations Environment Programme [UNEP]. (2002). Industry as a partner for sustainable development. United Kingdom: The Beacon Press.

Zhu, Q., Sarkis, J., \& Lai, K. H. (2008). Green supply chain management implications for "closing the loop”. Transportation Research Part E: Logistics and Transportation Review, 44(1), 1-18. 